Acta vet. scand. $1961,2,267-280$.

From the Department of Animal Physiology, Endocrinology and Bloodgrouping. The Royal Veterinary and Agricultural College, Copenhagen, Denmark.

\title{
THE G AND H BLOOD GROUP SYSTEMS OF THE PIG
}

By

E. Andresen ${ }^{1}$ ) and A. Wroblewski ${ }^{2}$ ).

Immunogenetic studies of the pig have revealed the existence of at least seventeen blood group factors in the erythrocytes of this species as surveyed by Andresen, Larsen, and Neimann-S $\phi$ rensen (1959). The blood group factors were classified into nine presumed blood group systems based mainly on population studies. However, family studies have now shown that the only known blood group factor, $\mathrm{P}_{\mathrm{a}}$, in the presumed $\mathrm{P}$ system actually is a factor of the $H$ system.

Details of investigations on two iso-immune antisera from which the reagents $G_{b}$ and $H_{b}$ were isolated will be presented. The results in section $A$ will indicate that $G_{a}$ and $G_{b}$ are a pair of contrasting characters; character $G_{a}$ was previously called $G$ (Andresen, 1957). Evidence will be presented for the existence of a multiple allelic blood group system at the $H$ locus in section B. The antigenic factors $\mathrm{H}_{a}$ and $\mathrm{H}_{b}$ are the first known factors of the system. Factor $H_{a}$ was previously called $H$, while factor $H_{b}$ is the $P_{a}$ factor mentioned above.

\section{MATERIAL AND METHODS}

The production of one of the iso-immune sera, " 57 ", used for the present study was described in a previous paper (Andresen

Present address:

1) Dept. of Animal Husbandry, Iowa State University, Ames, Iowa, U.S.A.

2) Experimental Breeding Laboratory, Polish Academy of Science, Warsaw, Poland. 
and Wroblewski, 1959). The other antiserum, "113", was likewise obtained by a series of weekly intravenous injections (eight in all) of citrated blood in amounts corresponding to 6-7 cc. of whole blood. The recipient pigs were bled one week after the last injection. The antisera were heated at $56^{\circ} \mathrm{C}$ for one half hour and stored at $-14^{\circ}$ to $-18^{\circ} \mathrm{C}$ with no preservative added.

The studies were made using blood samples from pigs of the Danish Landrace breed. One hundred forty-eight random blood samples (cf. Andresen and Irwin, 1959) were collected when the pigs were killed at the co-operative slaughterhouse in Hiller $\phi d$, Denmark. The majority of these samples, possibly all of them, originated from commercial herds. Furthermore, the material includes blood samples from boars and sows of 11 selected matings plus their respective offspring (cf. Table VI) as well as blood samples from 127 boars and sows from breeding centers at Zealand, Lolland, Falster, and $M \varnothing n$. The animals were bled by incision into an ear vein. The anticoagulant used was a solution of 2 per cent tri-sodium citrate, 0.5 per cent sodium chloride and 0.016 per cent sodium cyanide in distilled water. One volume of blood was collected into 4 to 10 volumes of this solution. Besides the blood samples mentioned above eight additional samples were used for the absorption experiments illustrated in Table I.

The following general procedure was used for absorption of antibodies. To one volume of appropriately diluted antiserum was added one half or an equal volume of three times washed and packed cells. However, only 0.2-0.4 volume of cells was used per volume of the $H_{b}$ reagent, diluted $l$ in 30 , when this reagent was "cross absorbed" (see p. 274).

Both antisera were reactive in a direct agglutination test; in addition the antiserum " 113 " was also reactive in a hemolytic test. One and one half per cent suspension of three times washed red blood cells in 0.92 per cent saline was used for these tests. The direct agglutination test was carried out at room temperature, $21^{\circ}-23^{\circ} \mathrm{C}$. One drop ( $\sim 0.05 \mathrm{cc}$.) of cell suspension was added to one drop of appropriately diluted antiserum in a 70by $10 \mathrm{~mm}$. test tube and shaken. The cells were allowed to settle for half an hour and shaken again. After an additional two and one half hours of incubation readings were made macroscopically and without any centrifugation. 
The hemolytic test was carried out at a temperature between $26^{\circ}$ and $28^{\circ} \mathrm{C}$. Two drops of antiserum and one drop of cell suspension were mixed in a test tube. After 15 minutes of incubation, one drop of complement was added, and the tubes were shaken. Readings were made after further one half hour, two hours, and three and one half hours of incubation. The tubes were shaken after the first and the second reading. The complement used was undiluted rabbit serum absorbed at $4^{\circ}-5^{\circ} \mathrm{C}$ with pig cells till free of species antibodies for these.

\section{EXPERIMENTAL}

A. Investigations on the antiserum " 57 ".

Preliminary investigations already published (Andresen and Wroblewski, 1959) indicated that antiserum " 57 " contained anti $E_{a}$, anti $E_{e}$, and a third population of agglutinins which could not be isolated because all the fifteen blood samples used for the experiment possessed the corresponding blood group factor, $G_{b}$. Therefore another fractional absorption experiment was carried out on the same antiserum. Blood samples from eight $\mathrm{E}(\mathrm{a}+\mathrm{e}+)$ individuals were used for the experiment. Small amounts of the antiserum were absorbed separately with red cells from each of these animals. The absorbed fractions were tested for presence of remaining agglutinins against blood cells from the same eight animals illustrated in Table $I$.

\section{Table I.}

Analysis of antiserum " 57 " by means of fractional absorption and subsequent tests for reactivity of the absorbed sera with each of eight blood samples (cf. the text).

\begin{tabular}{|c|c|c|c|c|c|c|c|c|c|c|}
\hline \multirow{2}{*}{$\begin{array}{l}\text { Test } \\
\text { cells }\end{array}$} & \multirow{2}{*}{$\begin{array}{l}\text { Relevant } \\
\text { antigens }\end{array}$} & \multirow{2}{*}{$\begin{array}{l}\text { Reactions } \\
\text { before } \\
\text { absorption }\end{array}$} & \multicolumn{3}{|c|}{ Reactions } & \multicolumn{4}{|c|}{ after absorption with } & \multirow[b]{2}{*}{48} \\
\hline & & & 6 & 11 & 16 & 25 & 31 & $\mathbf{3 3}$ & $\mathbf{3 4}$ & \\
\hline 6 & $\mathrm{E}_{\mathrm{a}} \mathrm{E}_{\mathrm{e}}$ & + & $\cdot$ & $\cdot$ & • & • & • & . & $\cdot$ & • \\
\hline 11 & $E_{a} E_{e} G_{b}$ & + & + & $\cdot$ & $\cdot$ & $\cdot$ & · & $\cdot$ & $\cdot$ & + \\
\hline 16 & $E_{a}^{\tau} E_{e} G_{b}$ & + & + & $\cdot$ & • & $\cdot$ & - & $\cdot$ & • & + \\
\hline 25 & $E_{a} E_{e} G_{b}$ & + & + & $\cdot$ & $\cdot$ & $\cdot$ & · & $\cdot$ & $\cdot$ & + \\
\hline 31 & $\mathrm{E}_{\mathbf{a}} \mathrm{E}_{\mathbf{e}} \mathrm{G}_{\mathrm{b}}$ & + & + & $\cdot$ & · & $\cdot$ & $\cdot$ & $\cdot$ & · & + \\
\hline 33 & $\mathrm{E}_{\mathbf{a}} \mathrm{E}_{\mathbf{e}} \mathrm{G}_{\mathrm{b}}$ & + & + & $\cdot$ & - & $\cdot$ & - & $\cdot$ & . & + \\
\hline 34 & $E_{a} E_{e} G_{b}$ & + & + & $\cdot$ & · & $\cdot$ & $\cdot$ & $\cdot$ & $\cdot$ & + \\
\hline 48 & $\mathbf{E}_{\mathbf{a}} \mathbf{E}_{\mathbf{e}}$ & + & • & $\cdot$ & • & $\cdot$ & · & $\cdot$ & . & $\cdot$ \\
\hline
\end{tabular}


In this table the occurrence of agglutination is indicated with " + " while a dot corresponds to lack of visible reaction. Thus it appears that absorption with cells from 6 and 48 leaves agglutinins for the blood cells $11,16,25,31,33$, and 34 . In order to have sufficient amounts of this antiserum fraction for further investigations, a larger amount of raw antiserum " 57 " was absorbed with blood cells from individual 48. With this test-serum, anti $G_{b}$, the possibility of a serological or genetical association between $G_{b}$ and the blood factors already known could be investigated. Blood samples from 148 random pigs of Danish Landrace breed were tested for the presence of $G_{b}$ as well as the characters $A, E_{a}, E_{b}, E_{e}, F_{a}, G_{a}, H_{a}, H_{b}, I_{a}, J_{a}, K_{a}, K_{b}, K_{d}$, and $\left.G^{\prime 1}\right)$. The antiserum $G^{\prime}$ was produced by injecting pig red cells into a rabbit. The designation $G^{\prime}$ was completely arbitrarily chosen, and did not indicate any association with $G_{a}$ or $G_{b}$. How-

T a bl e I I.

The distribution of "positive" and "negative" reactions with anti $G_{b}$ relative to the reactions obtained with each of fourteen other reagents.

\begin{tabular}{|c|c|c|c|c|c|c|c|c|c|c|}
\hline & & & 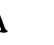 & & & & $b_{b}$ & & & $F_{\mathbf{a}}$ \\
\hline & & + & - & & - & + & - & + & - & +- \\
\hline & + & 28 & 113 & 18 & 123 & 65 & 76 & 132 & 9 & $16 \quad 125$ \\
\hline $\mathrm{G}_{\mathbf{b}}$ & - & 3 & 4 & 4 & 3 & 2 & 5 & 7 & 0 & 1 \\
\hline Probab & ity $\mathbf{y}^{\mathbf{1}}$ & & 16 & & .01 & & 31 & & 64 & 0.58 \\
\hline & & & & & & & b & $\mathbf{I}_{\varepsilon}$ & - & $+\mathbf{J}_{\mathbf{a}}$ \\
\hline & + & 44 & 97 & 61 & 80 & & 127 & 84 & 57 & $130 \quad 11$ \\
\hline $\mathbf{G}_{\mathbf{b}}$ & - & 7 & 0 & 4 & 3 & 0 & 7 & 4 & 3 & $\begin{array}{ll}7 & 0\end{array}$ \\
\hline Probabi & ity $\left.^{1}\right)$ & & 001 & & .37 & & .49 & & 59 & 0.58 \\
\hline & & & & & $\mathrm{K}_{\mathrm{b}}$ & & $\mathbf{r}_{\mathrm{d}}$ & & & \\
\hline & & & & & & & & + & - & \\
\hline & + & 57 & 84 & 58 & 83 & 8 & 133 & 141 & 0 & \\
\hline $\mathrm{G}_{\mathrm{b}}$ & - & 2 & 5 & 4 & 3 & 1 & 6 & 0 & 7 & \\
\hline Probabi & $\left.i^{i t y}\right)$ & & 42 & & 0.32 & & .36 & $<1$ & -11 & \\
\hline
\end{tabular}

1) Single-tail test.

1) The antiserum G' was kindly provided by Professor M. R. Irwin, University of Wisconsin. 
ever, anti $G^{\prime}$ and anti $G_{b}$ gave identical results when tested in parallel against the 148 blood samples (cf. Table II). This, combined with the fact that the two antisera were produced independently, makes it likely that they have the same specificity and contain only one fraction of antibodies. The population studies were therefore carried out without making further absorption tests on anti $G_{b}$.

The distribution of the phenotypes $G(b+)$ and $G(b-)$ relative to the other blood groups is shown in Table II. The association between $G_{b}$ and $G^{\prime}$ has been considered already. It will be seen that in the two comparisons involving $E_{a}$ and $G_{a}$ the probability values are 0.01 and below 0.001 , respectively (single tail tests). Lack of proportion in the first of these comparisons is most probably due to chance alone. On the other hand the probability $P^{*}<0.001$ of obtaining the results involving $G_{a}$ by chance (Table II) strongly suggested an association between $G_{a}$ and $G_{b}$. It is of special interest that no individual lacked both $G_{a}$ and $G_{b}$. Hence, the hypothesis was advanced that the two factors were contrasting in a closed genetic system.

In order to get further support for the two-allele theory a gene frequency analysis was applied. The results from blood tests on the 127 boars and sows from breeding centers were included in this analysis. The chi-square test (Table III) indicates no significant difference between the numbers of phenotypes in the two subsamples $(2 \times 3$ contingency Table). The gene frequencies were therefore calculated from the total material.

Table I I I.

The distribution of phenotypes in subsamples of 148 pigs from commercial herds and 127 pigs from breeding centers, and the total number of observed and expected phenotypes.

\begin{tabular}{|c|c|c|c|c|c|}
\hline \multirow{2}{*}{ Phenotype } & \multirow{2}{*}{ Genotype } & \multirow{2}{*}{$\begin{array}{l}\text { Nos. of pigs } \\
\text { from commer- } \\
\text { cial herds }\end{array}$} & \multirow{2}{*}{$\begin{array}{l}\text { Nos. of pigs } \\
\text { from breed- } \\
\text { ing centers }\end{array}$} & \multicolumn{2}{|c|}{ Total } \\
\hline & & & & Obs. & Exp. \\
\hline $\mathbf{G}_{\mathrm{a}}$ & $G^{a} G^{a}$ & 7 & 1 & 8 & 7.86 \\
\hline$G_{a}^{a} G_{b}$ & $G^{a} G^{b}$ & 43 & 34 & 77 & 77.28 \\
\hline $\mathrm{G}_{\mathrm{b}}$ & $G^{b} G^{b}$ & 98 & 92 & 190 & 189.86 \\
\hline Total & & 148 & 127 & 275 & 275.00 \\
\hline Chi-square & & \multicolumn{2}{|c|}{$\begin{aligned} \chi^{2}= & 4.2,2 \text { d.f. for } \\
& \text { homogeneity }\end{aligned}$} & \multicolumn{2}{|c|}{$\chi^{2}=0.0036,1$ d.f } \\
\hline
\end{tabular}


According to the two-gene theory there are two allelic genes, $G^{a}$ and $G^{b}$, either of which determines the presence of the equivalent antigen on the red cells. This theory implies that the frequencies for $G^{a}$ and $G^{b}$ may be obtained as follows:

$$
\mathrm{q}_{G^{a}}=\frac{2 G_{a}+G_{a} G_{b}}{2 N} \text { and } q_{G}{ }^{b}=\frac{2 G_{b}+G_{a} G_{b}}{2 N}=1-q_{G}{ }^{a} \text {, }
$$

where the phenotype designations denote the numbers of phenotypes actually observed and $\mathbf{N}$ denotes the number of individuals examined. When these formulae are applied to the total material in Table III the following results are obtained:

$$
\mathrm{q}_{\mathrm{G}}{ }^{\mathrm{a}}=\frac{2 \times 8+77}{550}=0.1691 \quad \mathrm{q}_{\mathrm{G}}{ }^{\mathrm{b}}=\frac{2 \times 190+77}{550}=0.8309
$$

Knowing the gene frequencies, the expected number of individuals having $G_{a}, G_{a} G_{b}$, and $G_{b}$ blood can be calculated under the assumption of genetic equilibrium in respect to $G^{a}$ and $G^{b}$. A comparison with the numbers actually observed will show whether the results are internally consistent and also consistent with the theory. The expected numbers are calculated as follows:

$$
\begin{aligned}
& \text { Expected numbers of } G_{a}=N \cdot q_{G^{a}}^{2} \\
& \text { Expected numbers of } G_{a} G_{b}=2 N \cdot q_{G^{a}} \cdot q_{G^{b}} \\
& \text { and expected numbers of } G_{b}=N \cdot q_{G}^{2} b
\end{aligned}
$$

The results of the calculations are given in Table III. The agreement between the observed and expected numbers within each of the three phenotypic classes of individuals is even closer than might be expected. The chi-square value 0.0036 means that an agreement as good or better will only arise purely by chance once in about twenty testings of 275 samples of blood from pigs of Danish Landrace breed. Thus, the agreement with expectations supports the two-allele theory for the G blood group system.

\section{B. Investigations on the antiserum " 113 ".}

Antiserum " 113 " was found to contain both agglutinating and hemolyzing antibodies against the donor cells. In order to $_{0}$ isolate possible unknown antibodies in this antiserum a blood typing test was made using test cells from 26 individuals including the donor and the recipient. Red cells from these individuals were tested with antiserum " $113^{\prime \prime}$ and eight other testsera (Table IV). 
Table IV.

Reactions of test cells from 26 individuals, including recipient and donor, with antiserum "113" and with eight reagents. "Positive" reactions which do not parellel those obtained with any of the eight reagents are indicated with " $\oplus$ ".

\begin{tabular}{|c|c|c|c|c|c|c|c|c|c|c|}
\hline \multirow{3}{*}{$\begin{array}{l}\text { Test } \\
\text { cells }\end{array}$} & \multicolumn{10}{|c|}{ Reactions of test cells with antiserum " 113 " and eight reagents } \\
\hline & \multicolumn{2}{|c|}{ “113" } & \multirow[b]{2}{*}{$\mathbf{A}$} & \multirow[b]{2}{*}{$\mathbf{E}_{\mathbf{a}}$} & \multirow[b]{2}{*}{$\mathbf{E}_{\mathbf{b}}$} & \multirow[b]{2}{*}{$\mathbf{E}_{\mathbf{a}}+\mathbf{E}_{\mathbf{e}}$} & \multirow[b]{2}{*}{$\mathbf{F}_{\mathbf{a}}$} & \multirow[b]{2}{*}{$\mathbf{G}_{\mathbf{b}}$} & \multirow[b]{2}{*}{$\mathbf{K}_{\mathbf{a}}$} & \multirow[b]{2}{*}{$\mathbf{K}_{\mathbf{b}}$} \\
\hline & $\begin{array}{c}\text { Aggluti- } \\
\text { nation }\end{array}$ & $\begin{array}{c}\text { Hemo- } \\
\text { lysis }\end{array}$ & & & & & & & & \\
\hline Recipient 113 & - & - & + & - & + & + & • & - & $\cdot$ & + \\
\hline Donor 119 & + & + & - & + & - & + & + & + & - & + \\
\hline 1 & + & + & . & . & . & + & + & + & + & - \\
\hline 2 & • & + & • & • & - & + & • & + & + & + \\
\hline 3 & - & + & . & • & + & . & . & + & + & $\cdot$ \\
\hline 4 & + & + & + & + & + & + & + & + & + & . \\
\hline 5 & - & - & • & $\cdot$ & + & + & • & + & • & + \\
\hline 6 & + & $\oplus$ & + & . & + & + & + & + & . & + \\
\hline 7 & - & . & . & • & + & • & • & + & • & + \\
\hline 8 & - & - & . & . & + & + & - & + & $\cdot$ & + \\
\hline 9 & + & $\oplus$ & . & + & + & + & - & + & $\cdot$ & + \\
\hline 10 & . & . & • & . & + & + & . & + & $\cdot$ & + \\
\hline 11 & + & + & . & • & + & + & + & + & + & • \\
\hline 12 & + & + & • & + & • & + & • & + & + & - \\
\hline 13 & . & + & . & . & + & + & . & + & + & • \\
\hline 14 & + & + & • & + & . & + & + & + & + & $\cdot$ \\
\hline 15 & • & • & • & $\cdot$ & + & • & • & + & $\cdot$ & + \\
\hline 16 & . & $\oplus$ & • & . & + & + & - & + & • & • \\
\hline 17 & . & $\oplus$ & + & . & + & + & . & + & • & - \\
\hline 18 & . & . & . & . & + & + & - & + & . & • \\
\hline 19 & • & + & + & • & + & + & • & + & + & • \\
\hline 20 & + & . & . & $\cdot$ & - & + & + & + & • & + \\
\hline 21 & . & + & + & . & . & + & . & + & + & . \\
\hline 22 & + & + & • & . & • & + & + & + & + & - \\
\hline 23 & + & $\oplus$ & . & . & • & + & + & + & . & + \\
\hline “Sor $\phi "$ & + & + & - & . & + & . & + & + & + & - \\
\hline
\end{tabular}

According to the reactions indicated for the donor and the recipient, anti $E_{a}$, anti $F_{a}$, and anti $G_{b}$ were the immune-antibodies to be expected in antiserum " 113 ". The recipient serum contained agglutinating antibodies whose reactions with the test cells paralleled those obtained with anti $E_{a}$ plus anti $F_{a}$. In addition, however, the test cells which were reactive with the $\mathrm{K}_{\mathrm{a}}$ reagent were also reactive with the recipient serum when this was used in a hemolytic test. Several examples of naturally oc- 
curring $K_{a}$ antibodies have been encountered in sera from Polish pigs, so there seems to be no reason to speculate on other possible explanations for the presence of the $K_{a}$ antibodies in this instance. The recipient serum also hemolyzed the cells from five $\mathrm{K}_{\mathrm{a}}$ negative individuals. These reactions are indicated in Table IV with " $\oplus$ " and correspond to $\mathrm{H}_{\mathrm{b}}$ reactions.

An absorption experiment was made using the "Sor $\varnothing$ " cells. This absorption completely removed antibodies for the characters $F_{a}$ and $K_{a}$ but left the $E_{a}$ and $H_{b}$ antibodies. The $E_{a}$ antibodies were subsequently removed by absorption with cells from individual no. 4 leaving only the unknown antibodies, anti $H_{b}$. When 14 aliquots of this $H_{b}$ antiserum were seperately re-absorbed with the cells from each of 14 random pigs with which the antiserum reacted, each of the aliquots was completely exhausted for reactivity against any of the 14 blood samples. The $14 \mathrm{H}(\mathrm{b}+)$ blood samples are those indicated in Table V. A control absorption with "negative" cells was carried out simultaneously to show that the removal of antibodies was specific. The result of this "cross-absorption" experiment combined with the relatively low frequency of the $\mathrm{H}_{\mathrm{b}}$ factor (cf. Table V) makes it likely that the prepared antiserum contains antibodies of only one specificity.

Ta b l e V.

The distribution of "positive" and "negative" reactions with the $H_{b}$ reagent relative to the reactions obtained with each of twelve other reagents.

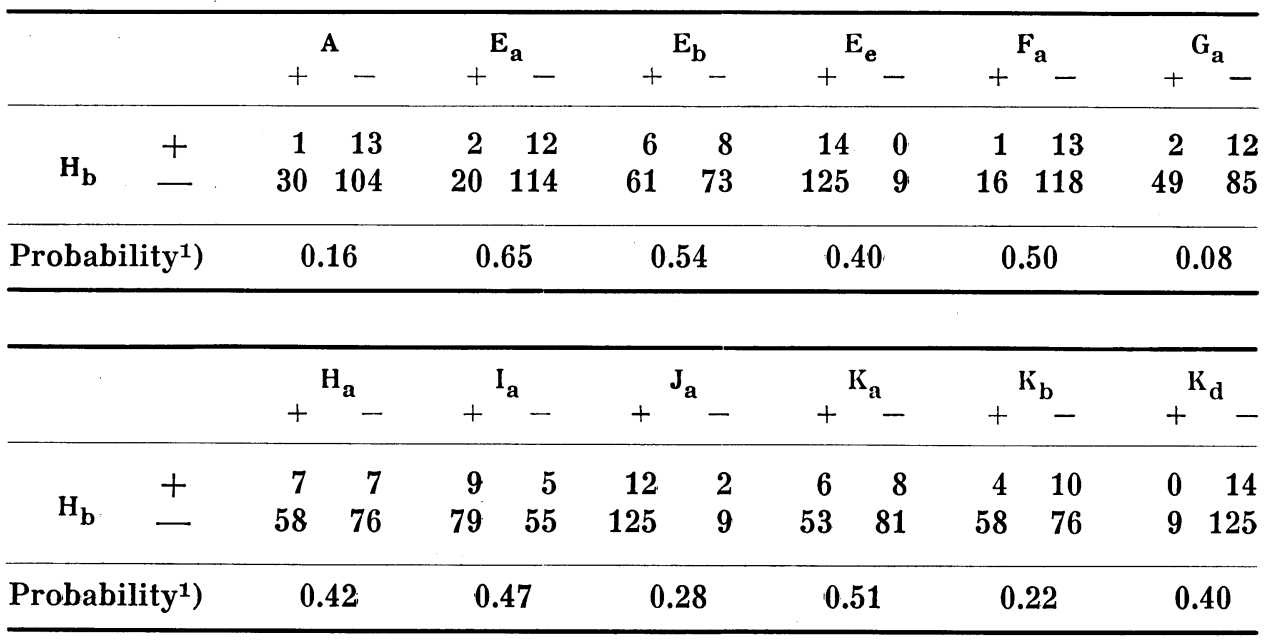

1) Single-tail test. 
As already shown in Table II, section A, no association was found between $H_{b}$ and $G_{b}$. Likewise, from the results indicated in Table $\mathrm{V}$ there seems to be no association between the distribution of $H_{b}$ positive and $H_{b}$ negative reactions, and those obtained with twelve additional reagents including the $H_{a}$ reagent. Still, an apparent lack of association is not conclusive proof of non-allelism. In this instance the lack of association is due to the low incidence of $\mathrm{H}_{b}$ individuals combined with a moderately low $\mathrm{H}_{\mathrm{a}}$ frequency. For the same reason a gene frequency analysis as was applied for the $G^{a} G^{b}$ system (cf. Table III) would not have given any indication of $\mathrm{H}^{\mathrm{a}} \mathrm{H}^{\mathrm{b}}$ allelism.

However, association between $H_{a}$ and $H_{b}$ appeared very likely when blood samples from 127 random boars and sows from breeding centers were tested with the $H_{b}$ reagent and with a hemolytic $\mathrm{H}_{\mathrm{a}}$ “dosage-reagent", $\stackrel{+}{\mathrm{H}}$ :

\begin{tabular}{l|cc|r}
\multicolumn{3}{c}{ Reactivity with the $\begin{array}{c}+ \\
\text { H reagent } \\
\text { "weakly or } \\
\text { negative" }\end{array}$} & \\
\hline $\mathrm{H}(\mathrm{b}+)$ & "strongly" & $\left.2^{1}\right)$ & 7 \\
$\mathrm{H}(\mathrm{b}-)$ & 5 & 115 & 120 \\
\hline & 10 & 117 & 127
\end{tabular}

1) Both $\stackrel{+}{\mathrm{H}}$ negative.

$$
P^{*}=\frac{7 ! 120 ! 10 ! 117 !}{127 !} \cdot\left[\frac{1}{2 ! 5 ! 5 ! 115 !}+\frac{1}{6 ! 4 ! 116 !}+\frac{1}{7 ! 3 ! 117 !}\right]<0.0001
$$

The low probability value strongly suggested an association between the two reagents. This was confirmed by a re-examination of the results of previous blood typing. It was thereby found that red cells from a majority of $\mathbf{H}(\mathbf{a}-\mathbf{b}+)$ individuals had actually reacted weakly when tested with the $\stackrel{+}{H}$ reagent, whereas red cells from $\mathrm{H}(\mathrm{a}-\mathbf{b}-)$ individuals did not react at all with this reagent.

To see if the serological association between $H_{a}$ and $H_{b}$ reflected a genetical association as well, the distribution of $\mathrm{H}_{\mathbf{a}}$ and $\mathrm{H}_{\mathrm{b}}$ reactions was examined for offspring from all matings in which at least one parent possessed both $H_{a}$ and $H_{b}$ (Table VI). 
T a b l e VI.

Observed and expected distribution of $\mathrm{H}(\mathrm{a}+\mathrm{b}-), \mathrm{H}(\mathrm{a}-\mathrm{b}+), \mathrm{H}(\mathrm{a}+\mathrm{b}+)$, and $\mathrm{H}(\mathrm{a}-\mathrm{b}-)$ offspring from three different mating types.

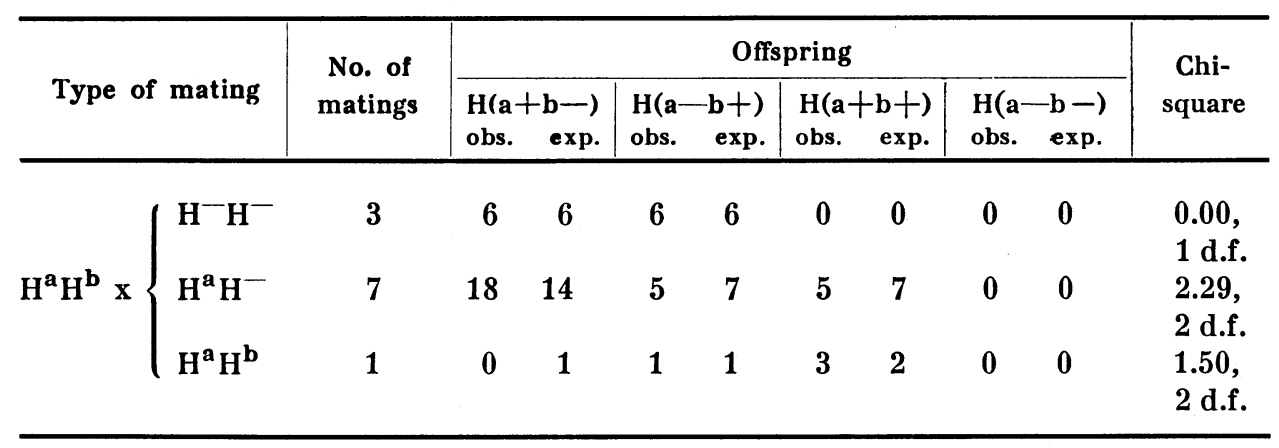

The available data are limited due to the relatively low frequency of $\mathrm{H}_{b}$ individuals. Still, it is apparent from Table VI that the data are consistent with the assumption that $H_{a}$ and $H_{b}$ are produced by allelic genes. Thus the known phenotypes and corresponding genotypes of the $\mathrm{H}$ system may be summarized as follows:

$$
\begin{array}{lr}
\text { Phenotypes } & \begin{array}{r}
\text { Genotypes } \\
\mathbf{H}(\mathbf{a}+\mathbf{b}-)
\end{array} \\
\mathbf{H}(\mathbf{a}-\mathbf{b}+) & \left\{\begin{array}{l}
\mathbf{H}^{\mathbf{a}} \mathbf{H}^{\mathbf{a}} \\
\mathbf{H}^{\mathbf{a}} \mathbf{H}^{-}
\end{array}\right. \\
\mathbf{H}(\mathbf{a}+\mathbf{b}+) & \left\{\begin{array}{l}
\mathbf{H}^{\mathbf{b}} \mathbf{H}^{\mathbf{b}} \\
\mathbf{H}^{\mathbf{b}} \mathbf{H}^{-}
\end{array}\right. \\
\mathbf{H}(\mathbf{a}-\mathbf{b}-) & \mathbf{H}^{\mathbf{a}} \mathbf{H}^{\mathbf{b}} \\
& \mathbf{H}^{-} \mathbf{H}^{-}
\end{array}
$$

This notation is based on the evidence for three alleles, $\mathrm{H}^{\mathrm{a}}$, $\mathrm{H}^{\mathrm{b}}$, and $\mathrm{H}^{-}$, where $\mathrm{H}^{-}$symbolizes the recessive allele for which no antigenic product is yet known.

\section{DISCUSSION}

Based upon present evidence the G system seems to be a closed two-allelic blood group system. However, this uncomplicated stage is likely to be temporary. Isolation of antibodies determining additional blood factors of the $G$ system is anticipated. The history of several blood group systems, notably human, strongly supports this point of view and the emergence of the human 
MNSs blood group system is especially illustrative for comparison (cf. Race and Sanger, 1959). Also the suilline E system may serve as an example for comparison. Factors $E_{b}$ and $E_{e}$ are contrasting characters and therefore analogous to $G_{a}$ and $G_{b}$. However, well characterized blood typing reagents are available for the detection of two additional blood group factors $E_{a}$ and $E_{f}$ of the $\mathrm{E}$ system. The four $\mathrm{E}$ reagents have been used for genetic studies which have revealed the existence of five different alleles in the $\mathrm{E}$ system as reported by Andresen et al. in 1960. The three alleles, $\mathrm{E}^{\mathrm{e}}, \mathrm{E}^{\mathrm{ae}}$ and $\mathrm{E}^{\mathrm{ef}}$, have the phenotypic product $\mathrm{E}_{\mathrm{e}}$ in common and the alleles $E^{b}$ and $E^{b f}$ have $E_{b}$ in common. The factors $G_{a}$ and $G_{b}$ might likewise be regarded as reflections of several different agglutinogens each of which is the product of a corresponding allele in a multiple allelic series. It should be emphazised that the gene symbols $G^{a}$ and $G^{b}$ must be regarded as potentially collective terms; in other words, $G^{a}$ and $G^{b}$ symbolize all possible genes each of which may cause the presence of the blood group factors $G_{a}$ and $G_{b}$, respectively, on the red blood cells.

In addition to the above suggested possibility for emergence of the G system one may also anticipate the existence of one or more alleles the antigenic product(s) of which cannot be detected even with very potent $G_{a}$ and $G_{b}$ reagents. The homozygous condition of such a gene, $G^{-}$, would correspond to a $G(a-b-)$ phenotype or a so-called "minus-minus phenotype". The existence of such phenotypes has been shown within most human blood group systems as surveyed by Race and Sanger (1959). The possible existence of a $\mathrm{G}^{-}$allele with a non-neglible frequency cannot be excluded based upon the results of the present study of population material comprising 275 individuals. However, it may be concluded from the present material combined with results from family studies yet to be published that the hypothetical allele $G^{-}$must occur with a very low frequency within pigs of Danish Landrace breed.

In red cell immunogenetics the relationship between phenotypic products (the blood group antigens) of allelic genes is often reflected in a more or less degree of serological cross-reactivity of the corresponding antibodies. This makes two-by-two contingency tables useful even in such cases where a genetical association cannot be shown due to small sample sizes and low gene frequencies. In this connection it should be noted that significant deviation from proportionality was only observed when 
the hemolytic $\mathrm{H}_{\mathrm{a}}$ reagent, $\stackrel{+}{\mathrm{H}}$, was used in parallel with the hemolytic $\mathbf{H}_{b}$ reagent. In contrast no lack of proportion was observed (Table $V$ ) when the hemolytic $H_{b}$ reagent was used in parallel with the original $\mathrm{H}_{\mathrm{a}}$ reagent which contains incomplete agglutinins and is used in an indirect Coombs test. These results are likely to be a reflection of a higher degree of serological similarity between two antibody populations of the same nature, in this case hemolysins, corresponding to contrasting characters, than between antibodies of different nature, hemolysins versus agglutinins, by means of which the same contrasting characters may be detected.

\section{ACKNOWLEDGMENT}

Grateful acknowledgment is made to Professor, dr. med. vet. Johs. Moustgaard, Head of Department of Animal Physiology, Endocrinology and Bloodgrouping, for continuous help and interest in the blood group studies.

The project was supported in part by the Danish State Scientific Foundation (Statens almindelige Videnskabsfond).

\section{REFERENCES}

Andresen, E.: Nord. Vet.-Med. 1957, 9, 274.

Andresen, E., N. Højgaard, B. Jylling, B. Larsen, J. Moustgaard and A. Neimann-Sørensen: Züchtkd. 1960, 32, 306.

Andresen, E. and M. R. Irwin: Acta agr. scand. 1959, 9, 253.

Andresen, E., B. Larsen and A. Neimann-Sфrensen: 16. internat. vet. Congr., Madrid. Main papers I. A. 2. 1959, 71.

Andresen, $E$. and A. Wroblewski: Nord. Vet.-Med. 1959, 11, 548.

Race, R. R. and R. Sanger: Brit. med. Bull. 1959, 15, 99.

\section{SUMMARY}

The present work is concerned with further investigations on a swine iso-immune antiserum in which three different populations of blood group antibodies have been detected. Two of these antibody populations, anti $\mathrm{E}_{\mathrm{a}}$, and anti $\mathrm{E}_{\mathrm{e}}$, are described previously (Andresen and Wroblewski, 1959).

A third antiserum fraction, containing anti $G_{b}$, has been isolated. The results from population studies on 148 random pigs of Danish Landrace breed from commercial herds made it likely that the two factors, $G_{a}$ and $G_{b}$, are contrasting characters in a closed genetic system. This theory was supported by a gene frequency analysis on combined material of 127 random pigs from breeding centers and the 148 random pigs from commercial herds. 
Also details of investigations on another iso-immune antiserum which contained anti $E_{a}$, anti $F_{a}$, anti $K_{a}$, and a fourth population of antibodies to be called anti $\mathrm{H}_{b}$ are presented.

Population studies on 127 random pigs suggested a serological association between $\mathrm{H}_{\mathbf{a}}$ and $\mathrm{H}_{\mathbf{b}}$. The possibility of detecting a genetical association was investigated. The results from blood typing limited family material are concordant with the theory that $\mathrm{H}_{a}$ and $\mathrm{H}_{b}$ are produced by allelic genes in a multiple allelic system.

\section{ZUSAMMENFASSUNG}

Die Blutgruppensysteme $G$ und $H$ beim Schwein.

Abschnitt A der vorliegenden Arbeit befasst sich mit weiteren Untersuchungen über ein iso-immunes Antiserum, in dem drei verschiedene Populationen von Blutgruppenantikörpern gefunden wurden. Zwei dieser Antikörperpopulationen, anti $\mathrm{E}_{\mathrm{a}}$ und anti $\mathrm{E}_{\mathrm{e}}$, wurden in einer früheren Veröffentlichung beschrieben (Andresen und Wroblewski, 1959).

Ein drittes Testserum, das anti $G_{b}$ enthält, wurde ausfraktioniert. Die Ergebnisse von Populationsuntersuchungen an einer Zufallsprobe von 148 Schweinen der dänischen Landrasse aus Mastbetrieben deutete an, dass die beiden Faktoren, $G_{a}$ und $G_{b}$, Alternativen in einem geschlossenen genetischen System sind. Diese Theorie wurde gestützt durch eine Genfrequenzanalyse an einem Gesamtmaterial von 127 Schweinen aus Zuchtbetrieben und oben erwähnten 148 Schweinen aus Mastbetrieben (Tabelle III).

In Abschnitt B sind Einzelheiten über Untersuchungen an einem anderen iso-immunen Antiserum mit den folgenden Antikörperpopulationen gegeben: anti $\mathrm{E}_{\mathrm{a}}$, anti $\mathrm{F}_{\mathrm{a}}$, anti $\mathrm{K}_{\mathrm{a}}$ und eine vierte Population, die als $\mathrm{H}_{b}$ bezeichnet werden soll.

Populationsuntersuchungen an 127 Schweinen aus Zuchtbetrieben deuteten an, dass eine serologische Beziehung zwischen $\mathrm{H}_{a}$ und $\mathrm{H}_{b}$ besteht. Auf Grund dieser Ergebnisse wurde nach Möglichkeiten gesucht, eine genetische Beziehung zu finden. Die Ergebnisse der Blutgruppenbestimmung an Tieren aus 11 Familien (Tabelle VI), sind in Ubereinstimmung mit der Theorie, dass die Faktoren $H_{a}$ und $H_{b}$ durch allele Gene in einem multiplen Allelsystem bedingt sind.

\section{SAMMENFATNING}

Blodtypesystemerne $\mathrm{G}$ og $\mathrm{H}$ hos svin.

Afsnit A omhandler fortsatte unders $\varnothing$ gelser af et iso-immun antiserum, hvori der er påvist tre forskellige blodtypeantistoffer. To af disse, anti $\mathrm{E}_{\mathrm{a}}$ og anti $\mathrm{E}_{\mathrm{e}}$, er beskrevet tidligere (Andresen \& Wroblewski, 1959).

Et blodtypereagens indeholdende det tredje af de nævnte antistoffer, anti $G_{b}$, er blevet fremstillet. Blodtypebestemmelse af 148 tilfældigt udvalgte slagterisvin samt 127 tilfældigt udvalgte søer og orner 
fra svineavlscentre viste, at G systemet må opfattes som et lukket genetisk system, der omfatter to allele gener $G^{a}$ og $G^{b}$.

Unders $\phi$ gelser af et andet iso-immun antiserum er beskrevet i afsnit $B$. Dette antiserum viste sig at indeholde antistoffer overfor blodtypefaktorerne $\mathrm{E}_{\mathrm{a}}, \mathrm{F}_{\mathrm{a}}$ og $\mathrm{K}_{\mathrm{a}}$ samt et fjerde antistof, anti $\mathrm{H}_{\mathrm{b}}$. Resultatet af blodtypebestemmelse af de 127 orner og søer fra avlscentre tydede på et serologisk slægtsskab mellem blodtypefaktorerne $\mathrm{H}_{\mathrm{a}}$ og $\mathrm{H}_{\mathrm{b}}$. Dette muliggjorde tillige en genetisk sammenhæng, og resultatet af de påf $\varnothing$ lgende familieunders $\varnothing$ gelser underbygger den teori, at det genetiske grundlag for faktorerne $\mathrm{H}_{\mathrm{a}}$ og $\mathrm{H}_{\mathbf{b}}$ er to allele gener $\mathrm{i}$ et blodtypesystem, der omfatter mindst tre alleler, $\mathrm{H}^{\mathrm{a}}, \mathrm{H}^{\mathrm{b}}$ og $\mathrm{H}^{-}$.

(Received May 16. 1961). 